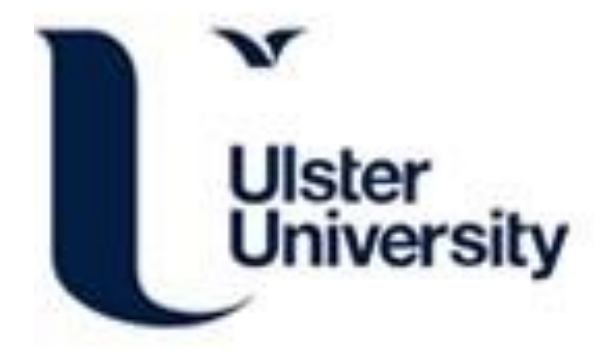

\title{
Lost in Transition: Governing Northern Ireland
}

Rouse, M., \& O'Connor, K. (2020). Lost in Transition: Governing Northern Ireland. In H. Sullivan, H. Dickinson, \& H. Henderson (Eds.), The Palgrave Handbook of the Public Servant (pp. 1-15). Palgrave Macmillan. https://doi.org/10.1007\%2F978-3-030-03008-7_19-1\#ESM

Link to publication record in Ulster University Research Portal

\section{Published in:}

The Palgrave Handbook of the Public Servant

Publication Status:

Published (in print/issue): 31/07/2020

DOI:

10.1007\%2F978-3-030-03008-7_19-1\#ESM

\section{Document Version}

Publisher's PDF, also known as Version of record

\section{General rights}

Copyright for the publications made accessible via Ulster University's Research Portal is retained by the author(s) and / or other copyright owners and it is a condition of accessing these publications that users recognise and abide by the legal requirements associated with these rights.

\section{Take down policy}

The Research Portal is Ulster University's institutional repository that provides access to Ulster's research outputs. Every effort has been made to ensure that content in the Research Portal does not infringe any person's rights, or applicable UK laws. If you discover content in the Research Portal that you believe breaches copyright or violates any law, please contact pure-support@ulster.ac.uk. 


\title{
Lost in Transition: Governing Northern Ireland
}

\author{
Michelle Rouse and Karl O'Connor
}

\section{Contents}

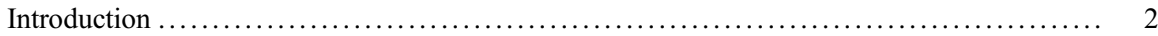

Bureaucrat Discretion and Political Control .................................... 2

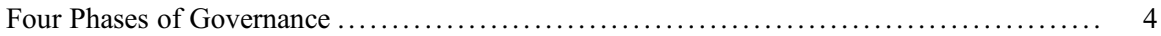

Phase One: Direct Rule ................................................ 5

Phase Two: Devolution 1999-2005 ..................................... 6

Phase Three: Power-Sharing 2006-2011 ................................. 8

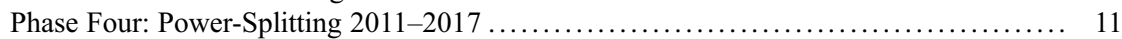

Toward a Framework of Politico-Administrative Relations ......................... 13

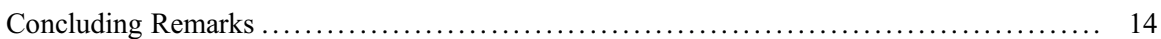

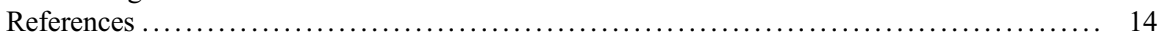

\section{Keywords}

Northern Ireland · Bureaucrat values · Administrative reform · Power-sharing

Nowhere in the UK has the public servant been as pivotal in developing and maintaining public services as in Northern Ireland (NI). The Northern Ireland Executive collapsed in January 2017, and until January 2020, no ministers had been appointed to represent the region. Of course, Northern Ireland has contended with absentee ministers from Westminster throughout its recent history; however, never before have civil servants in the region experienced such a prolonged period without direct political oversight. It is therefore an opportune time to reflect on how the civil servant role evolved and adapted during those years of power-sharing. In this chapter, we reflect on the role conceptions of civil servants following the Good

M. Rouse $\cdot$ K. O’Connor $(\bowtie)$

University of Ulster, Newtownabbey, UK

e-mail: Rouse-M1@ulster.ac.uk; k.oconnor@ulster.ac.uk

(C) The Author(s), under exclusive licence to Springer Nature Switzerland AG 2020 
Friday Agreement, the period from December 1999 until January 2017. Kaufman's (1956) bureaucratic values are used to create a conceptual framework for identifying the politics-administration dichotomy that underpins policy-making throughout this period. While there have been disruptions to the status quo in the interim, relations were permanently fractured in January 2017. Four stages of civil servant-politician relationship can be identified: delivery-oriented, combative, collaborative, and supplicant. We draw on documentary evidence and primary research to support these conclusions. This experience of the bureaucrat in Northern Ireland serves as a learning point for civil servants in other emerging power-sharing regimes - be these civil servants operating in Westminster having to engage with multiparty rather than single-party government or civil servants operating in an environment emerging from conflict where power-sharing has been identified as the most appropriate mechanism of conflict management.

\section{Introduction}

The separation of administration from politics lead to the development of the discipline of public administration. While in traditional Weberian and Wilsonian doctrines of public administration the bureaucrat was supposed to serve, not represent, it has long been acknowledged that the boundaries between politics and public administration are increasingly porous. Kingsley (1944) argued that it did not matter whether a decision was made in Westminster or Whitehall - by the politician or the bureaucrat: as both shared the same norms, beliefs, values, and life experiences, both would make the same decision, given the same access to information. Even at this early stage, the lines between political and bureaucratic decision-making were coming into question. While much is known about politico-administrative relations in homogenous societies, much less is known about this relationship within the power-sharing environment. In this chapter, we draw on Kaufman's (1956) bureaucratic values to create a conceptual framework for understanding the politicoadministrative dichotomy within the contested society of Northern Ireland. We draw on interview and documentary evidence to trace this development over the past 20 years of power-sharing.

\section{Bureaucrat Discretion and Political Control}

Bureaucratic discretion has been acknowledged to exist extensively within the public administration: "The ubiquity of bureaucratic discretion makes the problem of administrative responsibility a central and enduring concern in American government. .." and has "forced scholars to grapple with problems of bureaucratic accountability, responsibility and responsiveness" (Kaufman 1956 p172,179). The problems arising from bureaucrat discretion and political control have received extensive attention in the literature (Kaufman 1956; Meier and O'Toole 2006); however, less is known about the nature of this discretion within the power-sharing 
society and how this discretion changes over time. We therefore ask: What is the nature of politician-bureaucrat dichotomy, and how does this change over time?

Kaufman (1956) proposes that there are "three bureaucratic values" that guide bureaucratic reform: executive leadership, representativeness, and neutral competence. It is, Kaufman submits, the interaction of these three values that have determined the nature of public administration in the USA over time. Each of these values has been dominant, but not to the point of suppression of each of the others at various points in US history. The quest for representativeness began following American independence where the governor was appointed for very short terms and rarely had a veto over the legislature. In Kaufman's (1956, p1058) words:

the office was regarded as primarily ceremonial and a symbol of honour rather than as a seat of power, and it therefore rarely attracted men of distinction in the early days of the Republic...As one authority has remarked, they served their short terms and returned to private life with few accomplishments behind them and nothing before them but the pleasure of being called "Governor" for the rest of their days.

What followed was the quest for neutral competence in the early nineteenth century. As the industrial system developed, "corruption beset legislatures, from county boards and city councils right up to Congress itself, and the venality and incompetence of many public officers and employers were common knowledge" (Kaufman $1956 \mathrm{p} 1059$ ). This movement sought to take public administration out of politics, giving birth to the politics-administration dichotomy. The final quest for executive leadership came in the 1940s where the Office of the American President expanded considerably. He now had numerous advisers and sought to directly influence many aspects of governance:

chief executives, in whom administrative responsibility and power were to be lodged, were also partisan politicians....Gradually, therefore, the politics-administration dichotomy fell out of favor in public administration, and the doctrine of the continuity of the policyformulating process, better suited to the aims of executive leadership, began to replace it (Kaufman 1956, p1067)

Despite the sequential development of these values, Kaufman reiterates that while at each stage a value is dominant, the new value supersedes, not replaces the former. We use these bureaucratic values as a mechanism for analyzing the politico-administrative dichotomy within the power-sharing society. Mengistu and Vogel (2006:205) remind us that it is bureaucratic values that underpin administrative reforms, and if these "fundamental bureaucratic values are unexamined, the tension between reform efforts and applied civil service values may manifest as obstacles to democratic reform...." Kaufman's theory speaks directly to the "competencies of a skilled, effective bureaucracy" (ibid) and is, therefore, a useful conceptual lens to understand the politician-bureaucrat dichotomy in transition.

Interview participants were identified by theory-driven purposive sampling and snowballing: methods employed in recognition of their specific utility for 
populations from which interviews can be hard to elicit (Bleich and Pekkanon 2015, p9). Overall 22 semi-structured interviews were conducted between May and November 2018 with elite-level civil servants (grades 5 and above). In addition to current senior civil servants, four former senior civil servants were identified as a result of snowballing. All consented to interview. All interviews were digitally recorded, transcribed, and fully anonymized. Interview length ranged from $1 \mathrm{~h}$ to $1 \mathrm{~h} 45 \mathrm{~min}$. Interviews were coded and analyzed thematically using NVivo software. Braun and Clarke's model of thematic analysis (2006) was selected as an appropriate method for identifying, analyzing, and reporting patterns within data that would facilitate the capture of rich detail. Interview data was triangulated with transcripts of evidence provided to the Renewable Heat Incentive inquiry. ("The RHI Inquiry has been established to investigate a particular government scheme - the non domestic renewable heat incentive scheme - which was set up to assist in complying with obligations imposed by the law of the European Union in the area of renewable energy. The Northern Ireland scheme, which has similarities to a scheme in Great Britain, was devised and implemented by the then Department of Enterprise, Trade and Investment. The scheme's purpose was to provide a financial incentive for businesses to move away from non-renewable sources of energy. However, how the scheme came about in the form in which it was adopted, how it has been operated and the possible financial consequences of the scheme have become the source of considerable public concern. The RHI Inquiry will investigate the circumstances surrounding this scheme" RHI terms of reference.).

The Renewable Heat Incentive was a flawed green energy scheme that precipitated the collapse of power-sharing government in NI. A subsequent independent public inquiry into the Renewable Heat Incentive (RHI) identified complex failings in governance. During 114 days of public hearings, testimony from senior civil servants, ministers, and special advisers (SPADs) exposed a litany of problems and dysfunction at the heart of government. For our purpose, the RHI inquiry has provided an unprecedented insight into the workings of devolution and the nature of the politico-administrative relationship.

The following sections identify the politico-administrative dichotomy through Northern Ireland's four phases of governance in recent history. The subsequent section analyzes this evidence, generating a conceptual framework for mapping this dichotomy through the four phases.

\section{Four Phases of Governance}

A review of the literature leads us to define four phases of governance in Northern Ireland's recent history: direct rule, devolution, a honeymoon period where powersharing became established, and finally the power-splitting phase where the political parties split power along ethno-political lines. We discuss each of these phases in turn below. 


\begin{tabular}{|l|c|c|c|}
\hline Phase One \\
$1972-1999$ \\
Direct Rule
\end{tabular}$>\begin{gathered}\text { Phase Two } \\
1999-2005 \\
\text { Devolution }\end{gathered} \quad \begin{gathered}\text { Phase Three } \\
2006-2012 \\
\text { Power-sharing }\end{gathered}\left|\begin{array}{c}2014-2017 \\
\text { Power-splitting }\end{array}\right\rangle$

\section{Phase One: Direct Rule}

The proroguing of NI's Parliament in 1972 as a response to escalating civil conflict heralded a period of direct rule from London. During this period, temporary administrative arrangements for Northern Ireland involved the appointment of a Secretary of State and up to four junior ministers. These interim arrangements became entrenched as a state of "permanent impermanence" (Bloomfield 1998 in Knox and Carmichael 2005, p97) until devolution to a new Northern Ireland Assembly in 1999.

Direct rule ministers were frequently responsible for up to two NI departments in addition to their Westminster and constituency obligations. In this regional context, the nature of direct engagement between ministers and NI bureaucrats was considered "sporadic and superficial" (Carmichael and Osborne 2003, p208). Bureaucrat relationships with local politicians were equally distant. Legislation from Northern Ireland processed at Westminster was largely processed by virtue of statutory instrument. Unlike parliamentary bills, statutory instruments are not subject to amendment. In the absence of an active scrutiny role, NI bureaucrats could anticipate similarly sporadic and superficial engagement with local politicians over the course of their career. The position of the senior bureaucrat as a largely autonomous entity during the period is succinctly captured by Morison and Livingstone (1995, p154):

the comparatively small number of these officials and their relative public invisibility has accentuated the idea of government by an elite, a sense captured by the notion that all important decisions are taken in six key dining rooms in North Down.

The policy role of the NI bureaucrat during the period of direct rule was circumscribed to one of modest adaptation and delivery of policy designed at Westminster. As one senior civil servant commented:

We didn't do much policy in Northern Ireland because we didn't have to. Policy was something that arrived from Westminster and the job, not to oversimplify it, was scoring out 'England and Wales' and inserting 'Northern Ireland' in a policy paper or a piece of legislation. When you are not exercising a skill over a long period of time, it tends to atrophy. We also lost whatever political astuteness that we had - we had become disconnected from the local body politic because for 30 years it wasn't necessary to listen to people. It was only necessary to look to Westminster. (From Knox 2009)

The delivery-orientated nature of the NICS policy function operated in aberration of the equilibrium between design and delivery: 
we were very much a delivery civil service, and the balance was off, any public service has to have both. (Interview 20)

Scott Bollens' (2000, p230) study identifies the neutral strategy adopted by policy-makers in Northern Ireland in the mid-1990s - policy-making relied on technical rational data in resource allocation, and policy-makers distanced themselves from issues of ethnic identity, power inequalities, and political exclusion. Citizens were treated as individuals, not as being from a particular community, giving rise to the term color-blind policy-making (Bollens 2000).

In summary, dynamics from above (the Whitehall model) and below (drivers for symmetry in conflict management) evidence a strong neutrality norm within the bureaucracy during this period. The role of the bureaucrat during the direct rule period is further characterized by limited interface with politicians, the absence of a scrutiny role, and an atrophy in NICS policy development capacity and responsiveness. Viewed through the lens of Kaufman's three competing bureaucratic values (neutral competence, representativeness, and executive leadership), the absence of locally elected politicians suppresses drivers for executive leadership and representativeness. Bureaucrat role conception is firmly rooted in neutral competence.

\section{Phase Two: Devolution 1999-2005}

The 1998 Good Friday Agreement set out arrangements for the establishment of new political institutions in Northern Ireland, among them the creation of a legislative assembly, spearheaded by a multiparty executive, firmly grounded in principles of consociational power-sharing (Lijphart 1969). The politician bureaucrat relationship is considered here in the context of the transition from servicing remote majoritarian government to the exigencies of complex multiparty consociation. We further reflect on relationship-building in the context of attempts by local politicians to assert newfound authority and bureaucratic reactions to heightened local scrutiny and exposure. Finally, we consider the relationship against the intermittency of devolution in the period and the failure to bed in new institutional arrangements. In light of these considerations, we argue that the absence of trust and collective purpose calibrated a politico-administrative dynamic which functioned combatively in this period.

The transition to devolved power-sharing required a paradigm shift for the Northern Ireland Civil Service from its previous delivery function under direct rule to a live policy-making environment. The new political landscape required a high degree of sophistication in the development of policy that could be both responsive to locally determined priorities and sufficiently nuanced to accommodate the diverse ideological perspectives within the multiparty NI Executive. In this regard, the NICS were distinctly unprepared. Knox and McMahon (2014:3-4) note that many civil servants lacked requisite skills in policy formulation because of their reliance under direct rule on the "read-across" of policies from Westminster. The combination of a need to develop capacity within the bureaucracy taken with local political actors' 
need for quick deliverables in validation of political risks taken in the context of the Good Friday Agreement reveals an immediate mismatch in expectation and capacity.

Initial politician-bureaucrat relations additionally bore the hallmarks of a legacy of distrust and suspicion which had developed in the context of direct rule. Local politicians had traditionally regarded NI bureaucrats as "remote and unresponsive" (Carmichael and Osborne 2003, p214) and were keen to assert their newfound authority:

One thing I would say that was probably quite strong was [...] senior civil servants felt and understood that there was probably a suspicion of the civil service by the parties. We'd been there during direct rule you know and there was a certain element of 'right, were in charge now.' (Interview with former SCS (Interview 17))

Equally, senior NI bureaucrats were distinctly underwhelmed by the caliber of local politicians, the majority of whom had no direct experience of Belfast. Government, regarding them as "parochial and lacking in strategic vision" (Carmichael and Osborne 2003). Arrangements for Northern Ireland Assembly Committees differed dramatically from the "light-touch" approach NI bureaucrats had previously experienced within the Westminster committee system. As a feature of NI's distinct power-sharing arrangements, committee chairs were often selected in opposition to the designation of the departmental minister. A department headed by a Unionist minister, for example, would have a Nationalist as committee chair. This symmetrical arrangement designed to encourage cooperation between community designations laid the foundations for an adversarial character to the exercise of committee scrutiny functions. Committees can be said to have embraced with some aplomb their ability to summon departmental officials and papers. Carmichael (2002, p182) recounts how the proactive approach to scrutiny taken by some Assembly Committees caused a measure of "discomfort and resentment" among some senior officials.

The development of politico-administrative relations during this period was significantly inhibited by intermittency and inability to consolidate new powersharing arrangements. During the period, the institutions were suspended by the Secretary of State on four separate occasions. Formal direct rule from Westminster was reintroduced between 11 February 2000 and 20 May 2000 with two 1-day suspensions (11 August 2001 and 21 September 2001). The inability to secure requisite political consensus for the nascent institutions culminated in the eventual decision on 14 October 2002 to place them in cold storage, pending a further round of political negotiations to resolve outstanding issues. With the institutions embroiled in perma-crisis, the attention of elite political actors remained firmly focused on institutional power plays at the expense of the development of a distinct policy program or collective identity.

Returning to Kaufman's model of competing bureaucratic values (neutral competence, representativeness, and executive leadership), we argue that in terms of bureaucrat role conception, neutrality remained ascendant, mediated by a procedural if not yet substantive representativeness on account of new (de facto if not yet de jure) power-sharing institutional arrangements. Executive leadership, however, 
remains critically impeded by the failure to consolidate a collective executive identity and agenda.

\section{Phase Three: Power-Sharing 2006-2011}

\section{The Political Environment}

Following elections in November 2003, the DUP and Sinn Féin emerged as the largest parties, fundamentally altering the balance of power in NI. The DUP's refusal to share power with Sinn Féin, however, precipitated a further collapse of the Northern Ireland Assembly. A parallel process of confidence-building measures ensued. Measures which included commitments toward demilitarization and assurances in respect of the decommissioning of IRA weapons paved the way for a further round of multiparty negotiations. A deal brokered by the British and Irish Governments at St Andrews in October 2006 ushered forth the next phase in the governance of Northern Ireland: a period of genuine power-sharing. In addition to agreement for the restoration power-sharing institutions and a commitment for the devolution of policing and justice powers, the deal included provisions for a statutory Ministerial Code, circumscribing the capacity for any single minister or party to make significant decisions outside of the collectivity of the NI Executive.

During this period, a newfound rapport is widely considered to have displaced enmity between the two main parties. Former enemies, DUP's First Minister Ian Paisley and Sinn Féin's Deputy First Minister Martin McGuinness, were popularly deemed the "chuckle brothers" on account of having "chuckled their way through devolutions bright new beginning" (Gordon 2017). The new political consensus withstood numerous challenges to cooperation: most notably the killing of two British soldiers and a PSNI officer in 2009. Unity was most acutely reflected in a joint press conference from the steps of Stormont castle presenting Peter Robinson (First Minister), Martin McGuinness (Deputy First Minister), and Hugh Orde (PSNI Chief Constable) in "an important and symbolic display of unity" (Knox 2010, p40). A further round of successful negotiations culminated in the Hillsborough Agreement in 2010 which paved the way for the devolution of hitherto contentious policing and justice powers. Notwithstanding this political consensus, it is the relationship between these Ministers and their civil servants that most interests us here.

In this phase, we consider changing civil servant role conceptions, the outworking of a conflict management role in the bureaucracy, and the emergent role of the special adviser. In this phase, politico-administrative relations have stabilized with political consensus enabling common purpose. The evolving relationship between NICS bureaucrats and politicians in this phase is captured by the then Head of the Civil Service, Sir Bruce Robinson (2008-2011), who described civil servants as the "mortar" between the political bricks, further acknowledging that civil servants had to "win the trust of politicians" who were initially wary of NICS - an organization which had for years been controlled from London (Chambers 2010). 
Robinson acknowledges that maintaining trust in the politician bureaucrat relationship in the content of the new political dispensation "requires a heightened political awareness among civil servants" (Chambers 2010). Of particular significance, however, is the translation of this "heightened awareness" into an active role for NI bureaucrats, as distinct from their counterparts at Whitehall. Robinson explains that it is vital to "have sensitivity to the political spectrum, and help ministers by testing out some of the points and tabling some of the issues that you're conscious other parties will be concerned about - all with the objective of facilitating an outcome that's satisfactory to the minister" (Chambers 2010). Robinson acknowledges that in the context of the new political dispensation, NI bureaucrats frequently find themselves "hammering out a consensus or common view" (Chambers 2010). Bureaucrats during this era are found to play a pivotal role in the day-to-day management of power-sharing (O'Connor 2012). This is a substantial departure from the role of the traditional civil servant. While traditionally the civil servant would serve the government of the day, in this period, the civil servant is also tasked with maintaining a coerced coalition government.

This period also witnessed the emergence of the special adviser (SPAD) as a key player in the decision-making process. What had previously been a two-way relationship had now become a tripartite relationship: this created a "new way of working that civil servants hadn't seen before. ...that the papers are filtered through special advisers" (Interview 19). In the days of phase two above (Mallon and Trimble), the SPAD "was just a filter in the sense that the papers would arrive with Mallon and Trimble still intact from they left the civil service but with their comments added," whereas in this new phase, this "has changed quite substantially in what gets to the minister is heavily changed before it gets there and that's probably where things changed quite dramatically" (Interview 19, 2018).

The changing nature of the politician-bureaucrat relationship is adeptly captured below:

It didn't really fully change in the first period of devolution 1999-2002, but subsequently in the second period of devolution from 2002 it appeared to change quite dramatically in that period. Suddenly you had this situation where the very senior civil servants were having to defer to special advisors for access to the minister or to influence the minister. Whereas prior to that permanent secretaries were god..Ministers wouldn't dared open their mouth without clearing with the permanent secretary beforehand. Even direct rule ministers would have been very cautious about moving without ...I can remember one famous permanent secretary in the Department of Agriculture who insisted that every submission went through him, nothing got to the minister without him seeing it. Now not all perm sec's do that, although there are a few of them who exercise that level of control. Suddenly you reverse that culture to a position where nothing got to a minister unless it was filtered through special advisers and that was quite a significant change for the civil service. (Interview 19, 2018)

This view is further substantiated by the interviewee below:

My view of what happened is when in 2007 when we got back in, there was just a growing confidence of the DUP and SF as things went on and civil servants were side-lined and since. I felt that personally, in my role, in which I would I have tried to find middle paths for things, 
middle ground and draft things with square brackets and all that sort of stuff was really not welcomed. I was just kind of told, [... .] just why are you doing that, that's not your role. That was a big difference. That evolved and got more and more political more like the European way or something. The political people do all the negotiating without involving the bureaucrats. (Interview 17, 2018)

Akin to O’Connor (2014, 2017), Knox and McMahon (2014:4) argue that:

the day-to-day responsibilities of civil servants have changed. The job of the civil servant has become one of a network manager dependent on the resources of other actors over which he/ she has limited authority.

Civil servants during this period operated in a shared power structure where decisions could not be made unilaterally by either the politician or the bureaucrat. These changes are not unique to the politician-bureaucrat dichotomy in Northern Ireland, but are reflective of changes across the Western world. Civil servants now work in:

a shared power world in which government shares authority with a range of people and organisations. This requires a new way of looking at policy development and implementation where public policies are co-designed and co-produced with those people and organisations that deliver and use public services. The role of civil servants is to exercise a much more pluralist approach by reaching consensus between competing interests in support of the Minister. (Knox and McMahon 2014, p43)

In his evidence to the RHI inquiry, Sir Malcolm McKibben, Head of the Northern Ireland Civil Service, (2011-2018) summarized politico-administrative relations during our phase two and phase three:

Very briefly, if you go back to 2007 whenever the Executive was formed, it brought together five different parties with very different economic, social and constitutional aspirations, and that first mandate between 2007 and 2011 was really about building trust between the parties, getting them to learn how to work together, and to stabilise the institutions. (Renewable Heat Incentive Inquiry 2018a p.64)

The evidence considered for phase three when overlaid with Kaufman's model of the competing bureaucratic values which mediate transition (neutral competence, representativeness, and executive leadership) suggests that executive leadership is held equitably by the politician and the bureaucrat as a consequence of developing trust and common purpose and the consolidation of institutional and interpersonal relationships. In addition, the role of the bureaucrat in "thrashing out" a consensus view attests to increased politicization and a move away from neutral competence. This analysis substantiates O'Connor's (2014) finding that bureaucrat role conceptions may evolve in powersharing to assume an active conflict management function, where policy development requires the incorporation of "heightened political awareness" necessary to chart a center course between ideologically opposed political protagonists. 


\section{Phase Four: Power-Splitting 2011-2017}

\section{The Political Environment}

Following changes to parliamentary rules, in 2016, both the SDLP (Nationalist) and UUP (Unionist) rejected their entitlement to seats in the multi-party executive in favor of forming the first official opposition since devolution. Governance arrangements almost collapsed four times during this phase. In 2013, Richard Haass and Meghan O'Sullivan attempted to broker a deal to resolve legacy issues from the conflict culminating in the Stormont House Agreement in 2014. In 2015, the Fresh Start Agreement focused on selected residual issues including the role of paramilitaries, the budget, welfare reform, legacy, and corporation tax. This period was characterized by political instability and institutional fragility, and, at times, the institutions were on the verge of collapse and, indeed, did collapse following the resignation of the Deputy First Minister in January 2017 (Renewable Heat Incentive Inquiry 2018a, p65). During this period, we argue that power was now split between both main parties, as opposed to "shared" in the context of an inclusive executive. Of relevance to our research question, the balance of power between the politician and bureaucrat now rested firmly with the politician and special adviser.

In his testimony to the RHI enquiry, Sir Malcom McKibbin, Former Head of the Civil Service, noted a shift in emphasis during this period. Notwithstanding a real determination to implement the commitments in the Programme for Government, "it quickly ran into some significant problems that affected the potential stability of the institutions, so it was a very fragile time" (Renewable Heat Incentive Inquiry 2018a, p64). During this period:

decisions were made by the Ministers. Any policy agreement that was being made was put up in a submission to the Minister and. . . both sides of the house had to sign that off. If the submission wasn't signed off, it went into a place we called brokerage, and it sat there until the two parties were able to reconcile their differences or amend the policy direction in one way or another. (Renewable Heat Incentive Inquiry 2018a, p67)

The level of engagement between the civil service and political level is demonstrated by Sir Malcolm McKibbin's evidence, which clearly articulates a brokering role for the bureaucrat between opposing political protagonists:

\footnotetext{
The biggest difference, I suppose, that my role involved during the time that I was head of Civil Service was the engagement in the annual political crisis negotiations. I mean, they took up months - months. I mean, there was a huge number of hours put into those negotiations, either between the five parties or, indeed, between the two parties and the British and Irish Government. I mean, that was a huge difference between what I would've done in another Department and what I was doing in OFMDFM. And that wasn't part of the job spec, let me tell you, at the beginning. (Renewable Heat Incentive Inquiry 2018a, p68)
}

The role of the elite civil servant had changed. The civil servant while still perceiving their role to "serve the government of the day" found this task now involved a higher level of real politics than civil servants were comfortable with. At the RHI enquiry, 
Permanent Secretary Dr. Andrew McCormick was asked if there was an unwillingness on the part of the civil service to say "No" to ministers, to which he responded:

There's probably a bit of apprehension that, if we raise these issues too often, we'll be seen as awkward. You know, unhelpful. (Renewable Heat Incentive Inquiry 2018b, p19)

The relationship narrative identified here resonates strongly with that identified in phase two where an imbalance of power and a level of mistrust characterizes the working relationship between the civil servant and political actors. A key distinction, however, between this phase and phase two is that the bureaucrat's access to the minister is now mediated by the special adviser in a tripartite arrangement:

The assumption was that you couldn't get to the Minister other than through the special adviser, and that's what the Minister was comfortable with, and had we realised that, actually, that was far from the case a bit sooner, we might have done things differently. (Renewable Heat Incentive Inquiry 2018b:134)

Dr. Andrew McCormick was directly questioned by the chair of the inquiry on the nature of the power dynamics between himself as departmental permanent secretary and the special adviser when it was revealed that potentially sensitive emails had been exchanged between two special advisers in respect of delays in the implementation of cost controls to prevent abuse of the flawed scheme. When pressed by the chairman if he, in his capacity as departmental accounting officer, may have asked to see the emails, Dr. McCormick responded:

they were mentioned to me in a way that in - in a way that conveyed quite clearly that I wasn't gonna see them. (Renewable Heat Incentive Inquiry 2018b, p44)

When pressed further, McCormick responded that even if he had asked for the emails:

I don't think I would've been given them. . . In the atmosphere and context of that time, that did not occur to me, and I'm clear I would've been rebuffed. ...I think the reality of what we'd got used to was that they were in charge, and had made - they'd made that very clear, from 2007 onwards, that things would be done their way. (Renewable Heat Incentive Inquiry 2018b, p44)

Dr. McCormick's account of power asymmetries in the politico-administrative relationship is affirmed by that of David Sterling, current Head of the NICS, then Permanent Secretary of the Department of Finance. Mr. Sterling similarly indicated that he had no knowledge of discussions which took place between the special advisers in his department with a special adviser in another department in respect of the scheme. Under questioning, Mr. Sterling articulated the view that "the special adviser is responsible to the Minister" (Renewable Heat Incentive Inquiry 2018, p16). The chair, however, interjected to point out that the special adviser was also a civil servant, to which Mr. Sterling acknowledges: 
Quite clearly the issue here is that I wasn't being advised. . of this engagement between the special advisers in the two Departments. (Renewable Heat Incentive Inquiry 2018c, p16)

During this phase, the politician and the adviser are demonstrating executive dominance (Kaufman 1956). Such a shift in authority is not necessarily unique to the contested society of Northern Ireland: back in 2004, Svara cautioned that "relationships [between politicians and administrators] are becoming ever more complex. World-wide, we are witnessing a reassertion of political control that could evolve into inappropriate interference." In this chapter, we have presented evidence to support this claim. Here the pendulum now rests firmly with Kaufman's concept of executive dominance; neutral competence is diminished by the increased politicization and the bureaucrats active conflict management role. Representativeness is also impacted by an attrition of inclusivity. The NI bureaucrat now serves a twoparty coerced coalition as opposed to the inclusive, consensus-based grand coalition envisaged by Lijphart (1969) in his original prescription for plural societies.

\section{Toward a Framework of Politico-Administrative Relations}

To examine the politico-administrative axis, we employ a conceptual framework based on Kaufman's seminal "three bureaucratic values" that guide bureaucratic reform: authoritarian (executive) leadership, representativeness, and bureaucratic neutrality. Recall, it is the interaction of these three values that have determined the nature of public administration over time. His framework, applied to Ethiopia by Mengistu and Vogel (2006), "provides a succinct illustration of the struggle that newly constituted governments in transitional states undergo." In the triangle below, we map the four phases onto Kaufman's theory of bureaucratic values. In Northern Ireland, we have seen a rebalancing of bureaucratic values over the past 20 years from neutrality and representativeness to executive dominance.

The phases of government identified above demonstrate the usefulness of Kaufman's theory for understanding the politico-administrative dichotomy. The overtly neutral values that guided the civil service under direct rule gave way to an uneasy, if sometimes acrimonious, relationship between politicians and bureaucrats in the early years of devolution (phase two). These years of power-sharing embodied the values of representativeness, while in the final phase of power-splitting, we see executive values dominating the bureaucrat-politician relationship. Figure 1 depicts the politico-administrative axis and the role of the elite-level bureaucrat therein during the 20 years of power-sharing.

Conceptually, in phase one - during direct rule - we expect the bureaucrat to be in delivery mode; policies are simply adapted from Westminster to the Northern Ireland context. In phase two, in the early days of power-sharing, the bureaucrat knows the system, and the politician is relatively inexperienced. The politician, new to the game, will be suspicious of the bureaucrat and his/her intentions. In the third phase, trust has built up between the politician and the bureaucrat and indeed between the former political rivals; we are now entering a more collaborative era where executive 


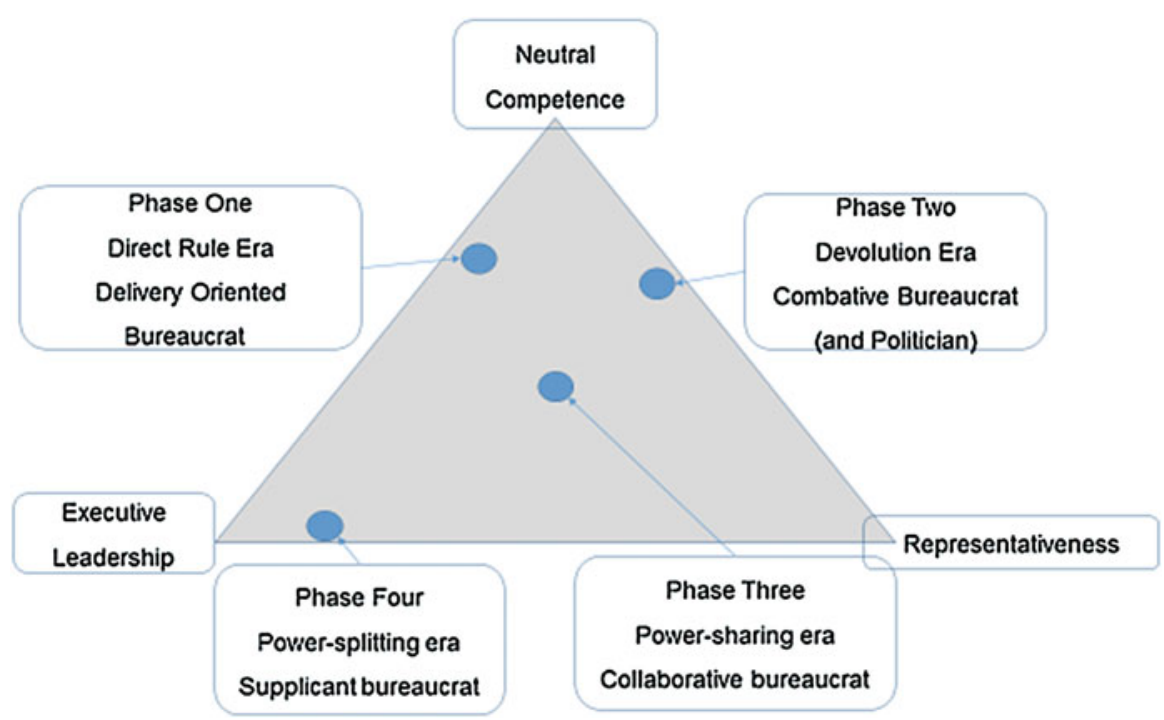

Fig. 1 Kaufman's competing bureaucratic values as manifest in Northern Ireland

leadership is mutually held by the bureaucrat and politician. Finally, in the fourth phase, the politicians know the rules of the game sufficiently and rely less on bureaucratic advice. In this scenario, politicians are firmly in control of executive leadership.

\section{Concluding Remarks}

The analysis presented above has developed a conceptual framework for understanding the bureaucrat-politician dichotomy within Kaufman's model of bureaucratic values. This template can be replicated in other contested societies to understand how the balance of power between politician and bureaucrats fits with the conflict management - conflict resolution trajectory. An understanding of politico-administrative relations will prove useful to those interested in understanding why the governance institutions have failed in Northern Ireland and those interested in learning from the Northern Ireland experience. Both politicians and bureaucrats have invested heavily in creating a peaceful and prosperous society; however, the balance between Kaufman's values has recently tipped toward executive leadership to the neglect of representativeness and neutrality.

\section{References}

Bleich, E., and R. Pekkanan. 2015. Data Access, Research Transparancy and Interviews. The Interview Methods Appendix. Qualitative and Multi Method Research 13 (1) 
Bloomfield, K. 1998. Central government. In People and government: Questions for Northern Ireland, ed. K. Bloomfield and C. Carter. York: Joseph Rowntree Foundation.

Bollens, S. 2000. On narrow ground: Urban policy and conflict in Jerusalem and Belfast. Albany: State University of New York Press.

Braun, V., and V. Clarke. 2006. Using thematic analysis in psychology. Qualitative Research in Psychology, 3 (2): 77-101. https://doi.org/10.1191/1478088706qp063oa

Carmichael, P. 2002. The Northern Ireland civil service characteristics and trends since 1970. Public Administration 80 (1): 23-49.

Carmichael, P., and R. Osborne. 2003. The Northern Ireland civil service under direct rule and devolution. International Review of Administrative Sciences 69 (2): 205-217.

Chambers, J. 2010. Interview: Bruce Robinson. Civil Service World. 1 Dec 2010. Available at https://www.civilserviceworld.com/profile-bruce-robinson.

Gordon, G. 2017. Ian Paisley's warmth to Martin McGuinness was no one off. BBC News Online. 20 Jan 2017. Available at http://www.bbc.co.uk.news/uk-northern-ireland-38695644.

Kaufman, H. 1956. Emerging conflicts in the doctrines of public administration. American Political Science Review 50 (4): 1057-1073.

Kingsley, D.J. 1944. Representative bureaucracy. Yellow Springs: Antioch Press.

Knox, Colin. 2009. Sink or swim for the Northern Ireland civil service. Parliamentary Brief, 3pp.

Knox, C. 2010. Devolution and the governance of Northern Ireland, 256. Manchester/New York: Manchester University Press.

Knox, C., and P. Carmichael. 2005. Improving public services: Public administration reform in Northern Ireland. Journal of Social Policy 35 (1): 97-120.

Knox, C.G., and D. McMahon. 2014. Professionalising the civil service: The masters in public administration. Perspectives on Pedagogy and Practice 5: 43-64.

Lijphart, A. 1969. Consociational democracy. World Politics 21 (2): 207-225.

Meier, K. J., and L.J. O’Toole. J. 2006. Political control versus bureaucratic values: Reframing the debate. Public Administration Review, 66: 177-192.

Mengistu, B., and E. Vogel. 2006. Bureaucratic neutrality among competing bureaucratic values in an ethnic federalism. Public Administration Review 66: 205-216.

Morison, J., and S. Livingstone. 1995. Reshaping public power: Northern Ireland and the British constitutional problem. London: Sweet and Maxwell.

O'Connor, K. 2012. Belfast revisited: Everyday policy making in a contested environment. Irish Political Studies 28 (1): 58-77.

- 2014. Public Administration in Contested Societies. Basingstoke: Palgrave.

2017. What are the ideas and motivations of bureaucrats within a religiously contested society. International Review of Administrative Sciences 69 (2): 205-217.

Renewable Heat Incentive. 2018a. Oral hearings. Day 110 Thursday 25 October 2018. Belfast: Renewable Heat Incentive Inquiry. Available from https://www.rhiinquiry.org/sites/rhi/files/ media-files/D110-Transcript-25Oct2018.pdf. Accessed 12 June 2019.

- 2018b. Oral hearings. Day 111 Friday 26 October 2018. Belfast: Renewable Heat Incentive Inquiry. Available from https://www.rhiinquiry.org/sites/rhi/files/media-files/D111Transcript-26Oct2018.pdf. Accessed 19 June 2019.

- 2018c. Oral hearings. Day 84 Wednesday $5^{\text {th }}$ September 2018. Belfast: Renewable Heat Incentive Inquiry. Available from https://www.rhiinquiry.org/sites/rhi/files/media-files/D84Transcript-05Sep2018.pdf. Accessed 10 June 2019.

Svara, J. 2004. The complementary pursuit of sound governance. PA Times 27 (2): 6. 